\title{
エナメル上皮腫の1例
}

水野治郎・竹松啓一・天野恵夫 - 河合宏一・福田順子・玉井健三

\section{A case of ameloblastoma}

\author{
Jiro Mizuno - Kehichi Takematsu - Shigeo Amano - Kohichi Kawai \\ Junko FuKuda - Kenzo TamaI
}

序論

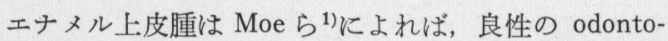
genic epithelial tumor であるが，臨床的には Shatkin ら 2)とよれば悪性腫瘍といわれているもので，口腔腫瘍 の中では一般に比較的まれな疾患の1つとされているが, わが国の文献考察では必ずしるこれに一致していないよ らである゙．

発生部位は，下頸臼歯部から下買隅角部とくに智歯部 が圧倒的に多く, 石川ら でその約 $3 / 4$ が下頼で, 大且歯から後方にかけて発現す るものであるとしている.

われわれは最近下顎正中部に発生し, 臨床的に単胞性 と見られる部位的にもきわめてまれな症例と思われるエ ナメル上皮腫の 1 例に遭遇したのでその概要を報告する.

症

例

患者：40才, 男性,

初診 : 昭和 46 年 10 月.

主訴：口底部の腫脹.

家族歴, 既往歴 : 特記すべき事項はない。

現病歴 : 昭和 43 年 8 月口腔底部に無痛性の腫脹を認め たが，増大する傾向もないので放置した. しかし 6 カ月 後腫脹の消退がないため, 某外科医を訪れ下笡骨腫瘍の 診断のもとに手術を受けた。昭和45年12月再び口腔底部 に腫脤を認めたが放置し，昭和46年10月腫脹の消退がな いため本院整形外科を受診したが，直ちに当科へ紹介さ れ来科した.

現症：全身所見は体格，栄養共に中等度でなんら異常 は認められない。

顔貌所見は左右不対称性で左側口角部からオトガイ部

金沢大学医学部付属病院歯科口腔外科

(科長 : 玉井健三助教授)

Clinic of Dent-oral Surgery, School of Medicine, Kanazawa University. (Chief : Assist. Prof. Kenzo Tamai)

受付 昭和 48 年 5 月 1 日

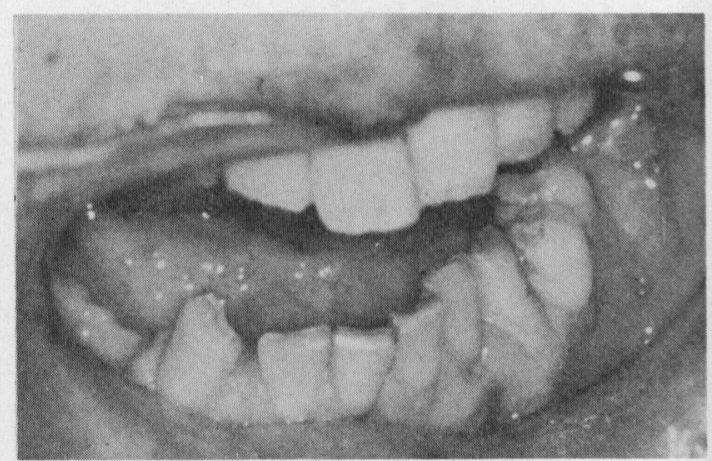

写真 1 口腔内写真, 歯牙莓玲症は認められない

そかけて手術性瘢痕を認め，わずかに腫脹を認める.

口腔内所見は口腔底部に腫脹を認め,オトガイ部の骨 壁は菲薄になり，羊皮紙様音がみられる、 $3 \sim 5$ 部歯肉の 膨隆を認めるも健康色を呈している．またその部の歯牙 に動摇を認め，打診痛を訴えるが，歯牙䝆玲症は認めら れない（写真 1)

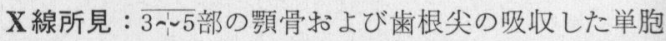
性の鷄卵大の境界明瞭な $X$ 線透過像を認める.（写真 2)

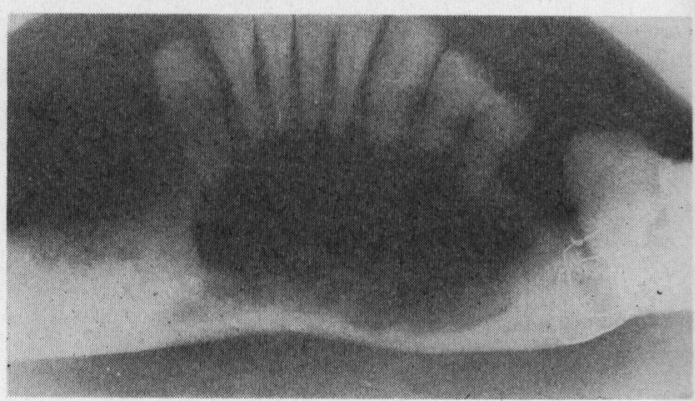

写真 2 下顎前歯部，パノラマX線像

臨床検查所見：血液一般検査, 生化学検查, 尿検査, 心電図所見の結果，特記すべき異常は認めなかった． 
表 1 臨床検㚗成續

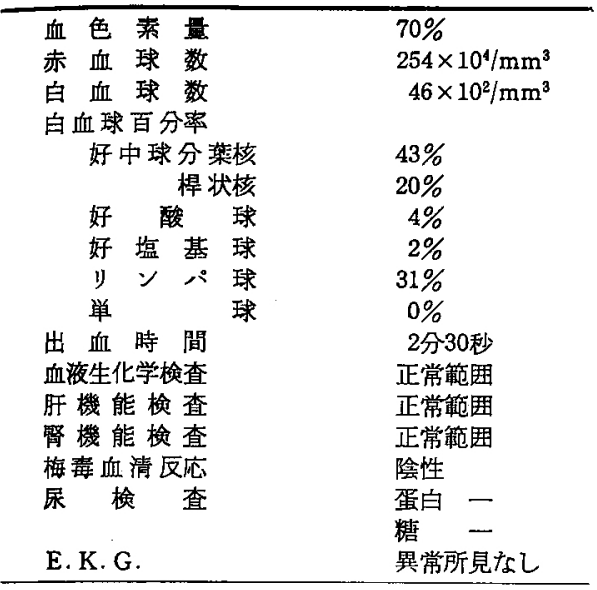

(表1)

監床診断：エナメル上皮腫の疑い。

手術ならびに経過 : 上記診断のもとに入院後，全身的 飞異常のないことを確認したので，経鼻插管 G.O.F. 全身麻䤃下のもとに下顎右側犬歯部より左側第 2 小目歯 部展顔側崡肉飞横切開を施し，粘膜骨膜を娳離後，骨削 除し腫場を一塊として摘出乙開放創にて手術を終了した。 街後の骨折予防の意味から Roger-Anderson の䫓外固 定術を併用した。

術後経過良好で骨折もなく，術後28日間で退院し，現 在約 1 年 6 カ月を経過するが再発もなく経過良好である.

摘出物所見：約 $4 \mathrm{~cm}^{3}$ の類球形状で，表面は乳黄色で チョコレート色の内容物を充満した一塊の襄胞であった.

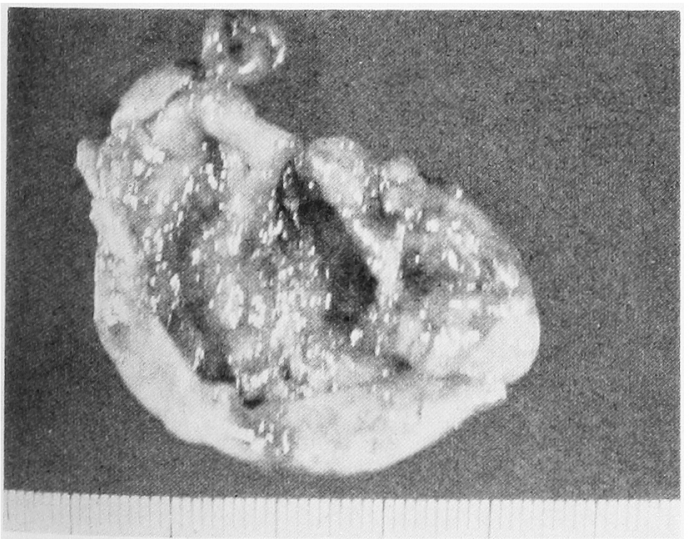

写真 3 摘出物所見全貌

病理組学的所見：10\%ホルマリン水溶液で固定後, 切片醥本を作製し通法にしたがってへマトキシリン・エ

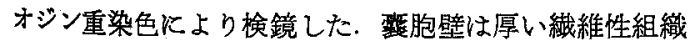
からなり，内面のところどころに胞状細胞の多い肉芽組 蟣をみる. 一部内面に棘上皮を主として扁平上皮層がお おっている. 実質はエナメル器に類似するが，胞篓の中
央部にあるエナメル䯣に類似した星状の細胞群があり， ところどころ角化機転が䜅められ扁平上皮の像を示す部 分も認められる。 また歯堤に似た細胞索が綎横に走って

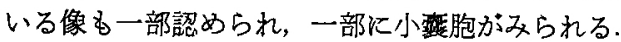

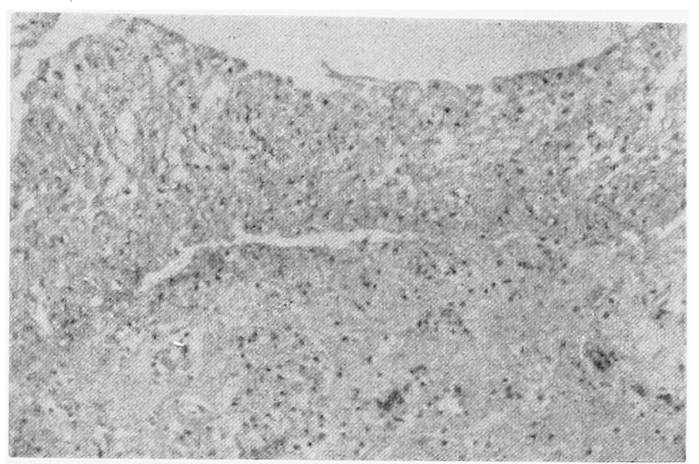

写真 4 病理組織像 $\mathrm{H}-\mathrm{E}$ 重染色. $\times 40$.

実質の角質变性部に石灰沈着は認めない，悪性変化に。 ない.

病理組織学的診断：エナメル上皮腫

$$
\text { 考案 }
$$

エナメル上皮腫は，好発部位として一般には下䫇曰歯 部から下顎角部，とくに智雪部が圧倒的に多いとされて いる. 下顎正中部に発生するエナネル上皮腫は部位的に きわめてまれなるのとされStanley られによれば，100例 の ameloblastoma のらら下顠前雪部に発生したものは 2 例のみであると報告している。本邦では平出すの報告 によると，下顎 109 症例中 3 例で下買前雪部に打ける ameloblastoma はきわめて少ない症例であるとしてい る. また最近の報告では，Dick ${ }^{6)}$ の下䫛前雨部に発生し た monocystic ameloblastoma の論文があるがきわめて まれな症例であるとされている. 本症例も Dick の報告 と全く部位部に一致する定例できわめてまれなるのと思 われる。

手術方法については，われわれは第 1 次処置法として 開空潦法を選択した。臨床的にレントゲン像から下顎下 緑の健康骨と思われる所見がかなり残存していること， 術中尰瘍を一塊として摘出し得たことにより開空療法を とった。

エナメル上皮腫は，しばしば再発をおこすといわれて おり，Small らうによれば 359 症例の顎骨の ameloblastoma の術後（始息的, 放射線療法, 摘出術, 電気焼灼 併用，顎切除）の再発率は約34\%であると報告している. しかしこの再発率は，処固方法に関係するるのとして平 出 ${ }^{5}$ は顎切除を行なった102例では再発は，約5\%にすぎ ないと報告している.

本証例の場合，口腔内からPartsch I 法で整胞摘出術 のごとく一塊として腫瘍の摘出を施行し，顎切除は行な 
わなかった，その理由として下顎前歯部であり，年令的 に若年者に属することによるすのであるが， Sugimura ら 8 の報告によれば，わが国の転移を伴った ameloblastoma について記載し, 原発が下䫇の ameloblastoma でその転移がリンパ節, 肺, 頸椎, 肩胛骨, 下口唇等に ある症例を報告し，また深谷ら帛によれば，10年経過後 に再発をみた症例をも報告していることから本症も今後， 充分経過観察をしていきたい。

\section{結論}

下顎前歯部といら部位的にきわめてまれと思われる ameloblastomaの 1 症例を報告した.なお術後約 1 年 6 カ月を経過する今日，再発の症候は認め得ない。

本論文の要旨は，第17回日本口腔外科学会総会において発表 した.

稿を終るに臨み，病理組織診断で御指導いたたいた金沢大学 医学部中央検査部松原藤教授ならびに東京医科齿科大学 口腔病理 学教室小守昭助教授に対し哀心より感謝の意を表し ます.

\section{文献}

1) Moe, H., Clausen, F. \& Philipsen, H.P. : The ultrastructure of the simple ameloblastoma. Acta Path Microbiol Scand 53:140 1961.

2) Shatkin, S. \& Hoffmeister, F.S. : Ameloblastoma : A rational approach to therapy. Oral Surg $20: 421$ 1965.

3）石川悟朗, 秋吉正豊 : 口腔病理学 II, 改装版, 永末書店, 京都, 1970, 908頁.

4) Stanley, H. R. \& Diehl D. L. : Ameloblastom poten. tial of follicular cysts. Oral Surg $20: 2601965$.

5）平出経布：エナメル上皮腫の臨床的ならびに病理学的研究 日口外誌. $4: 2141958$.

6) Dick, H.M. : Monocystic ameloblastoma with plexiform, spindle cell, and granular cell variants: J Oral Surg $27: 481969$.

7) Small, I. A. \& Waldron, C. A. : Ameloblastomas of tha jaws. Oral Surg $8: 2811955$.

8) Sugimura, M., T. Yamauchi., K. Yashikawa., N. Takeda., M.Sakita. \& T. Miyazaki. : Malignant ameloblastoma with metastasis to the lumbar vartebra. J Oral Surg $27: 3501669$.

9）梁谷昌展，佐藤弘喜，馬越秀雄，合内 㓮，判治準一郎： 上額に発生した adeno ameloblastoma の 1 例. 日口外詰 17: 411971. 